\title{
Prognostic Model for Corrosion-Inhibition of Mild Steel in Hydrochloric Acid by Crushed Leaves of Voacanga Africana
}

\author{
Charles Nwachukwu Anyakwo', Agha Inya Ndukwe \\ ${ }^{1}$ Department of Materials and Metallurgical Engineering, Federal University of Technology, Owerri, Nigeria \\ ${ }^{2}$ Department of Metallurgical Engineering Technology, Akanu Ibiam Federal Polytechnic Unwana, Afikpo, Nigeria
}

Email address:

ndukweaghainya@yahoo.com (A. I. Ndukwe)

\section{To cite this article:}

Charles Nwachukwu Anyakwo, Agha Inya Ndukwe. Prognostic Model for Corrosion-Inhibition of Mild Steel in Hydrochloric Acid by Crushed Leaves of Voacanga Africana. International Journal of Computational and Theoretical Chemistry. Vol. 5, No. 3, 2017 , pp. 30-41. doi: 10.11648/j.ijctc.20170503.12

Received: June 2, 2017; Accepted: June 15, 2017; Published: July 26, 2017

\begin{abstract}
The weight-loss technique was used to study the inhibition of the corrosion of mild steel in $0.7 \mathrm{M}, 1.2 \mathrm{M}$ and $2.2 \mathrm{M} \mathrm{HCl}$ by thoroughly crushed fresh-leaves of Voacanga Africana. The corrosion rate was observed to increase with increase in the concentration of acid. The maximum inhibition efficiency of $69.80 \%$ was obtained when thoroughly crushed leaves of Voacanga Africana was added at $15 \mathrm{~g}$ per litre of $0.7 \mathrm{M} \mathrm{HCl}$ with a corresponding decrease in corrosion rate from $2.6487 \mathrm{mg} . \mathrm{cm}^{-2} \cdot \mathrm{h}^{-1}$ to $1.3684 \mathrm{mg} . \mathrm{cm}^{-2} \cdot \mathrm{h}^{-1}$. The prediction of the corrosion rate by the artificial neural network gave a minimal error and was closer to the experimental corrosion-rate value in comparison with the prediction by multiple regression. Upon the variation of temperature between $298 \mathrm{~K}$ and $358 \mathrm{~K}$, the activation energy obtained for the corrosion of mild steel in the blank solution of $0.7 \mathrm{M} \mathrm{HCl}$ was $20,908.68 \mathrm{~J}$ while the addition of Voacanga Africana's crushed leaves at $15 \mathrm{~g}$ per litre of $0.7 \mathrm{M} \mathrm{HCl}$ increased the activation energy to $26,710.26 \mathrm{~J}$. The corrosion inhibition of mild steel in hydrochloric acid by the addition of the crushed plant-leaves is in agreement with the Langmuir adsorption isotherm with $\mathrm{R}^{2}=0.992$.
\end{abstract}

Keywords: Voacanga Africana, Crushed Plant-Leaves, Hydrochloric Acid, Artificial Neural Network, Multiple Regression, Inhibition Efficiency, Corrosion Rate, Mild Steel

\section{Introduction}

Corrosion is the deterioration of a metal owing to its reaction with the environment $[1,2]$. This development involves a gradual reversion to the more stable state such as oxide, sulphide or carbonate [3]. Allowing corrosion to unabatedly occur may lead to catastrophic consequences. However, corrosion can be prevented through cathodic protection, anodic protection, addition of inhibitors, coating and proper selection of materials. The method of corrosion prevention by the addition of inhibitors is pertinent to this study.

An inhibitor should be able to reduce the degradation of a metal when added in small amount to the corrosive environment. Benzimidazole and triazole derivatives are well known corrosion inhibitors that showed more than $97 \%$ of inhibition against acid corrosion of mild steel [4], but they are also known for their toxicity [5, 6, 7]. Notably, the toxic nature of the known effective inhibitors of arsenate- and chromate-based has necessitated the search for an alternative inhibitor that would not only be efficacious but environmentally friendly. Previous research has revealed the effectiveness of some plant-extracts in inhibiting the corrosion of metals and alloys. This present work aims at investigating the effectiveness of thoroughly crushed leaves of Voacanga Africana in reducing the hydrochloric acidinduced corrosion of mild steel.

The various species of the Voacanga genus are evergreen trees. They grow to a height of $6 m$ with a spread of $2 m$, but are usually kept smaller in cultivation. The stem is erect; the leaves are broadly oval and up to $30 \mathrm{~cm}$ long. The berries contain several brown seeds which are irregularly shaped, and grow in a cluster that sometimes can resemble a brain. The various species of the genus are very similar to one 
another, featuring yellow or white flowers with five united petals [8, 9]. A native of the West African rainforests, Voacanga Africana prefers rich soils in protected sunny to shady areas, and is tender to drought and frost. Propagation is from fresh seed or cuttings. Fresh seeds germinate much more quickly than older seeds [10].

The corrosion inhibition data are better understood by developing a mathematical model. Predictive models are produced using multiple regression and artificial neural network (ANN). In multiple regression, the relationship between the dependent variable (which is the corrosion rate in this study) and three independent variables (conc. of acid, quantity of crushed leaves and time of exposure) is evaluated. On the other hand, the working principle of the artificial neural network is similar to that of human nervous system [11].

\section{Methodology}

\subsection{Preparation of Crushed Leaves}

Fresh leaves of Voacanga Africana were obtained within the surrounding of the Federal University of Technology Owerri. The leaves were thoroughly crushed with a manual blender before being added to different concentrations of acid at $15 \mathrm{~g}$ per litre, $30 \mathrm{~g}$ per litre and $45 \mathrm{~g}$ per litre of $0.7 \mathrm{M}, 1.2 \mathrm{M}$ and $2.2 \mathrm{M} \mathrm{HCl}$.

\subsection{Fabrication of Mild Steel Coupons}

The Mild steel ((wt \%) $\mathrm{C}=0.20 \%, \mathrm{Zn}=0.75 \%, \mathrm{Ti}=0.28$, $\mathrm{Mn}=0.23 \%, \mathrm{~S}=0.04 \%, \mathrm{P}=0.035 \%$ and $\mathrm{Fe}$ balance) coupons of $4 \mathrm{~cm}$ by $4 \mathrm{~cm}$ by $0.15 \mathrm{~cm}$ dimensions were press cut from a sheet metal using a foot shear cutting machine. The mild steel coupons were ground down with coarse and fine emery papers and later cleaned with acetone before their initial weights were determined by the Ohaus electronic weighing balance.

\subsection{Weight-Loss Technique}

The weighed coupons were immersed in various

$$
\mathrm{R}_{\text {corr }}=\mathrm{k}_{\mathrm{o}}+\mathrm{f}_{1} \text { (time of exposure) }+\mathrm{f}_{2} \text { (conc. of acid) }+\mathrm{f}_{3} \text { (quantity of crushed leaves) }
$$

Where,

$k_{o}=$ Intercept on $R_{\text {corr }}$ axis.

$f_{1}=$ Change in $R_{\text {corr }}$ for each 1 increment change in time of exposure.

$f_{2}=$ Change in $R_{\text {corr }}$ for each 1 increment change in conc. of acid.

$f_{3}=$ Change in $R_{\text {corr }}$ for each 1 increment change in quantity of crushed leaves.

\subsubsection{Artificial Neural Network (ANN)}

Artificial neural network imitates the human brain in data analysis. It consists of a number of very simple and highly interconnected processors, also called neurons, which are similar to the biological neurons in the brain [13]. Figure 1 concentrations of hydrochloric acid to which different quantities of crushed leaves of Voacanga Africana had been added at $15 \mathrm{~g}$ per litre, $30 \mathrm{~g}$ per litre and $45 \mathrm{~g}$ per litre of $0.7 \mathrm{M}$, $1.2 \mathrm{M}$ and $2.2 \mathrm{M} \mathrm{HCl}$. Another experimental set-up which did not contain any inhibitor was prepared for the purpose of comparison. In every hour, a coupon was withdrawn from the study environment, thoroughly cleaned with acetone and reweighed to figure out the final weight. The experimentation lasted for eight hours. The above experimental procedure was repeated by varying the temperature between $298 \mathrm{~K}$ and $358 \mathrm{~K}$.

The rate at which the mild steel corroded was computed using the formula $[9,12]$ :

$$
\text { Corrosion rate, } \mathrm{R}_{\text {corr }}=\mathrm{w} /(\text { A.t })
$$

Where,

$w=$ Weight-loss.

$A=$ Exposed area.

$t=$ Time of exposure.

The inhibition efficiency occasioned by the addition of thoroughly crushed leaves of Voacanga Africana to the corrodent was obtained by the relationship:

Inhibition efficiency, I.E $(\%)=\left(\mathrm{R}_{\text {corr } 1}-\mathrm{R}_{\text {corr } 2} /\left(\mathrm{R}_{\text {corr } 1}\right)\right) * 100(2)$

$\mathrm{R}_{\text {corr } 1}=$ Corrosion rate of the uninhibited environment.

$\mathrm{R}_{\text {corr } 2}=$ Corrosion rate of the inhibited environment.

\subsection{Development of Predictive Model}

\subsubsection{Multiple Regression (MR)}

Multiple regression is a statistical tool that generates a mathematical model by evaluating the relationship between the dependent variable and two or more independent variables. In this study, the dependent variable is the corrosion rate $\left(\mathrm{mg} . \mathrm{cm}^{-2} . \mathrm{h}^{-1}\right)$ whilst the three independent variables are conc. of acid (M), quantity of crushed leaves $(\mathrm{g})$ and time of exposure (h). Using the principle of multiple regression, the model can be obtained by employing the formula:

illustrates the artificial neural network for the prediction of corrosion inhibition of mild steel in hydrochloric acid by thoroughly crushed leaves of Voacanga Africana.

The artificial network neurons are joined by weighted links which pass signals from one neuron to another as displayed in Figure 2. Each neuron obtains several signals from its input links, computes a new activation level and transmits it as an output signal. The neuron calculates the weighted sum of the input signals and compares the result with a threshold value. The other input to the neuron, $d_{j}$ is referred to as the bias, which is an arbitrary selected value that oversees the input of the network as depicted in equation (4) [14].
Where, 


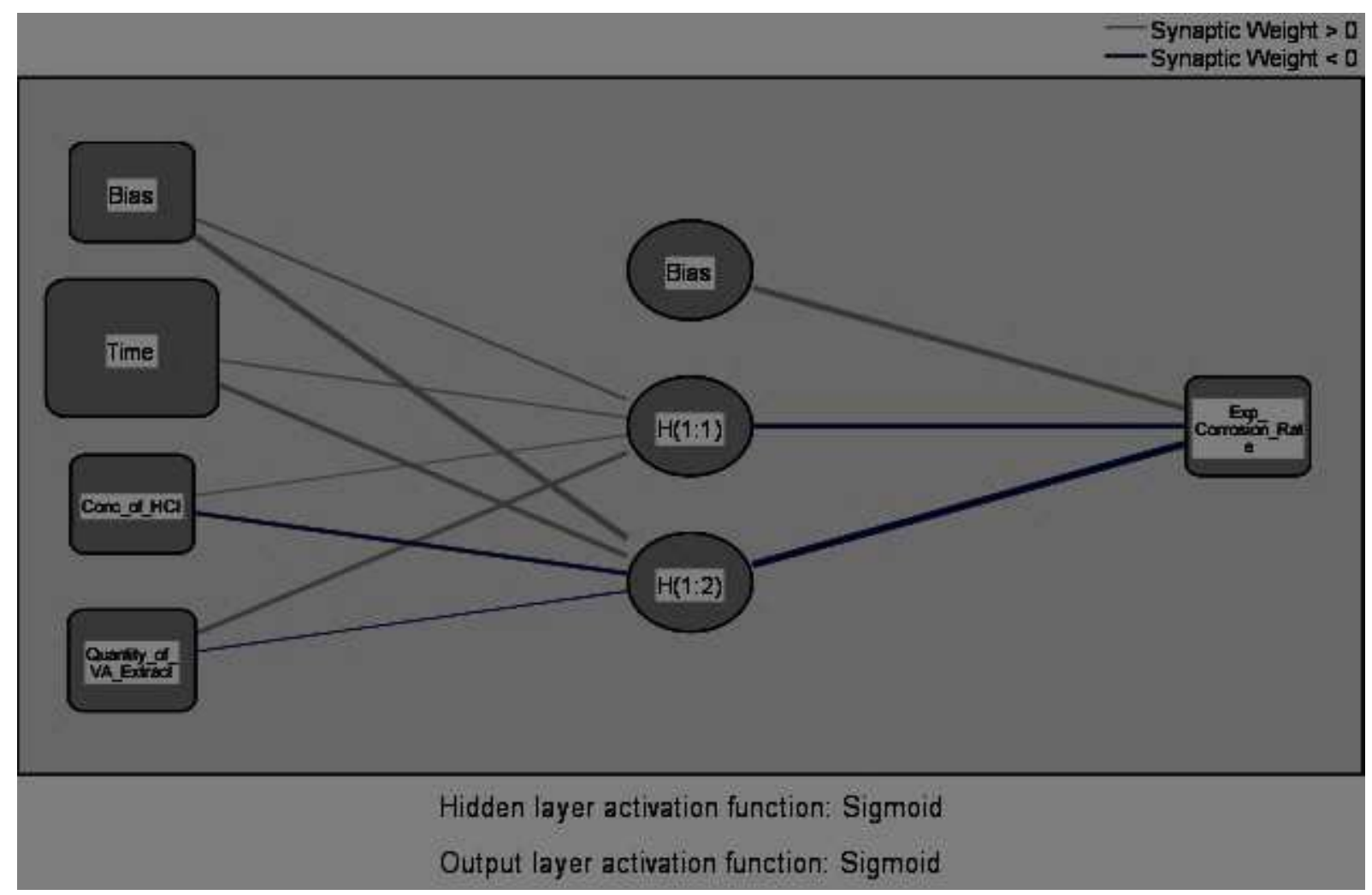

Figure 1. Artificial neural network for the prediction of corrosion inhibition of mild steel in hydrochloric acid by thoroughly crushed leaves of Voacanga Africana.

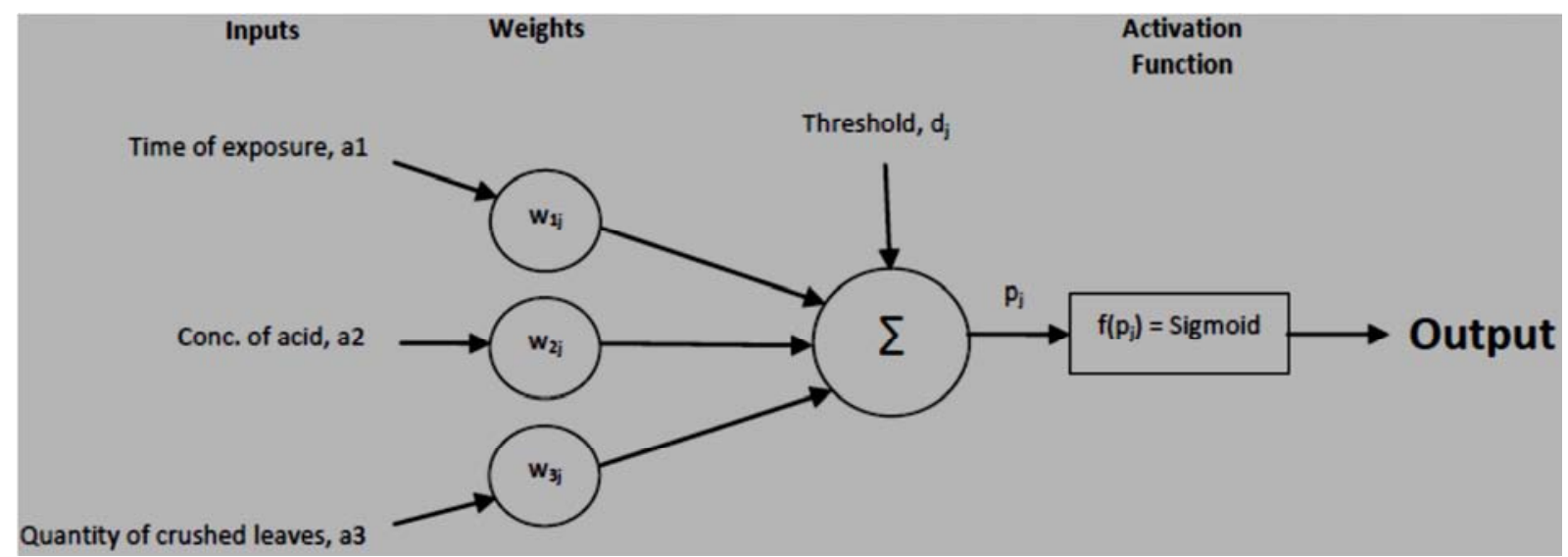

Figure 2. Schematic representation of the neuron.

According to [13], the neuron output is -1 if the net input is less than the threshold. But if the net input is greater than or equal to the threshold, the neuron becomes activated and its output attains a value +1 . The net input of the network is computed by using the equation below:

$$
\mathrm{p}_{\mathrm{j}}=\sum\left(\mathrm{a}_{\mathrm{i}} \cdot \mathrm{w}_{\mathrm{ij}}\right)+\mathrm{d}_{\mathrm{j}}
$$

Where,

$$
\begin{aligned}
& p_{j}=\text { Net input. } \\
& a_{i}=\text { Input of unit. } \\
& w_{i j}=\text { Weight } . \\
& d_{j}=\text { Bias of the unit. }
\end{aligned}
$$

The sigmoid function, $\mathrm{f}\left(\mathrm{p}_{\mathrm{j}}\right)$ transforms the input, which can have any value between plus and minus infinity, into a reasonable value in the range between 0 and 1 as given in equation (5) [14]. Neurons with this function are used in the back-propagation networks [13].

$$
\mathrm{f}\left(\mathrm{p}_{\mathrm{j}}\right)=1 /\left(1+\mathrm{e}^{-\mathrm{pj}}\right)
$$

Where, $p_{j}=$ Net input.

\subsubsection{Analysis of Error in Prediction}

The importance of error analysis in prediction is to investigate how close the predicted value is to the actual or experimental value. The error in prediction can be obtained by using the mean standard error (MSE) and the mean absolute error (MAE) whose formulae are stated below: 


$$
\begin{array}{lll}
\mathrm{MSE}=1 / \mathrm{N} \sum\left(\mathrm{C}_{\mathrm{i}}-\mathrm{D}_{\mathrm{i}}\right)^{2} & \text { (6) } & C_{i}=\text { Predicted value. } \\
\mathrm{MAE}=1 / \mathrm{N} \sum\left(\mathrm{C}_{\mathrm{i}}-\mathrm{D}_{\mathrm{i}}\right) & \text { (7) } & D_{i}=\text { True value. }
\end{array}
$$

Where,

$N=$ Number of samples.

\begin{tabular}{|c|c|c|c|c|c|c|}
\hline \multirow{2}{*}{$\begin{array}{l}\text { Exposure Time } \\
\text { (Hours) }\end{array}$} & \multicolumn{2}{|l|}{ 0.7M HCl } & \multicolumn{2}{|l|}{ 1.2M HCl } & \multicolumn{2}{|l|}{ 2.2M HCl } \\
\hline & $C R\left(\mathrm{mg} \mathrm{cm}^{-2} \cdot \mathrm{h}^{-1}\right)$ & I. E (\%) & $C R\left(\mathrm{mg} \cdot \mathrm{cm}^{-2} \cdot \mathrm{h}^{-1}\right)$ & I.E (\%) & $C R\left(\mathrm{mg} \cdot \mathrm{cm}^{-2} \cdot \mathrm{h}^{-1}\right)$ & I. E (\%) \\
\hline \multicolumn{7}{|c|}{ Addition of thoroughly crushed leaves of Voacanga Africana at $15 \mathrm{~g}$ per litre of $\mathrm{HCl}$} \\
\hline 1 & 2.6487 & 55.42 & 1.6351 & 28.46 & 4.5307 & 24.01 \\
\hline 2 & 1.8646 & 69.16 & 1.0078 & 35.74 & 2.2131 & 38.05 \\
\hline 3 & 1.3989 & 66.50 & 0.7900 & 28.89 & 1.4986 & 38.50 \\
\hline 4 & 1.4137 & 66.20 & 0.7493 & 36.25 & 1.1668 & 38.76 \\
\hline 6 & 1.3684 & 75.70 & 0.6661 & 36.38 & 0.8853 & 34.24 \\
\hline 7 & 1.3924 & 74.85 & 0.5838 & 44.12 & 0.7667 & 36.19 \\
\hline 8 & 1.3934 & 78.74 & 0.5820 & 37.26 & 0.7497 & 34.92 \\
\hline Average & 0.5115 & 69.80 & 0.8385 & 36.06 & 1.6095 & 34.60 \\
\hline \multicolumn{7}{|c|}{ Addition of thoroughly crushed leaves of Voacanga Africana at $30 \mathrm{~g}$ per litre of $\mathrm{HCl}$} \\
\hline 1 & 1.0688 & 59.65 & 1.8007 & 21.22 & 3.8686 & 35.12 \\
\hline 3 & 0.5547 & 60.35 & 0.6215 & 44.05 & 1.6167 & 33.65 \\
\hline 4 & 0.5322 & 62.35 & 0.7166 & 39.03 & 0.8394 & 55.94 \\
\hline 5 & 0.4560 & 67.92 & 0.6302 & 46.76 & 0.6366 & 59.41 \\
\hline 6 & 0.5450 & 60.17 & 0.5087 & 51.41 & 0.6399 & 52.47 \\
\hline 7 & 0.4373 & 68.59 & 0.3004 & 71.24 & 0.6659 & 44.58 \\
\hline 8 & 0.4358 & 68.72 & 0.3264 & 64.81 & 0.5525 & 52.04 \\
\hline Average & 0.5869 & 64.01 & 0.7118 & 48.52 & 0.5525 & 46.63 \\
\hline \multicolumn{7}{|c|}{ Addition of thoroughly crushed leaves of Voacanga Africana at $45 \mathrm{~g}$ per litre of $\mathrm{HCl}$} \\
\hline 1 & 0.8974 & 66.12 & 0.6354 & 72.20 & 3.7930 & 36.39 \\
\hline 2 & 0.6520 & 65.03 & 0.5896 & 62.41 & 1.6743 & 53.13 \\
\hline 3 & 0.5207 & 62.78 & 0.2962 & 73.34 & 1.2072 & 50.46 \\
\hline 4 & 0.3340 & 76.37 & 0.2127 & 81.90 & 0.9817 & 48.46 \\
\hline 5 & 0.4711 & 66.86 & 0.4932 & 58.34 & 1.0363 & 33.92 \\
\hline 6 & 0.4778 & 65.08 & 0.4410 & 57.88 & 0.8853 & 34.24 \\
\hline Average & 0.5145 & 68.45 & 0.3967 & 68.65 & 1.3700 & 42.40 \\
\hline
\end{tabular}

\section{Results}

Table 1. Effect of addition of thoroughly crushed leaves of Voacanga Africana on the corrosion of mild steel immersed in different concentrations of hydrochloric acid.

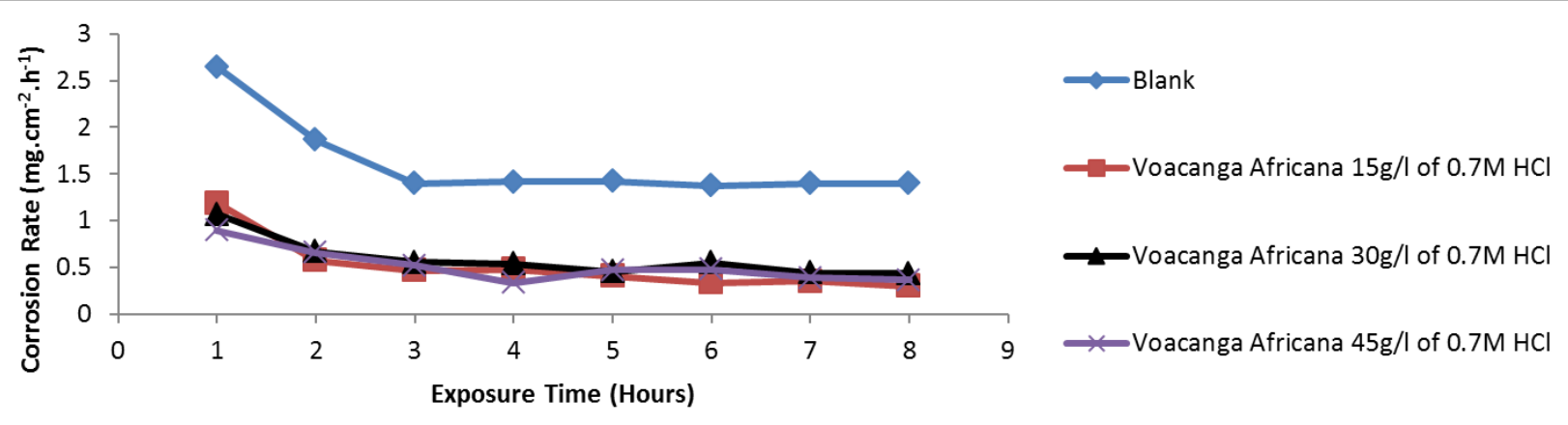




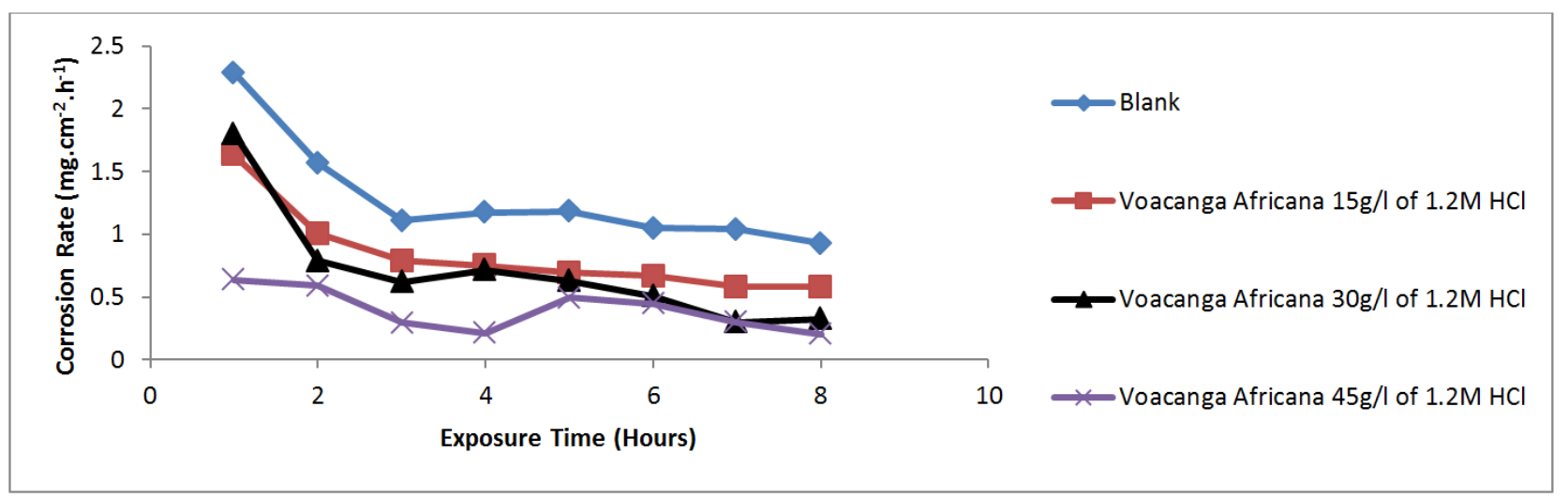

(b)

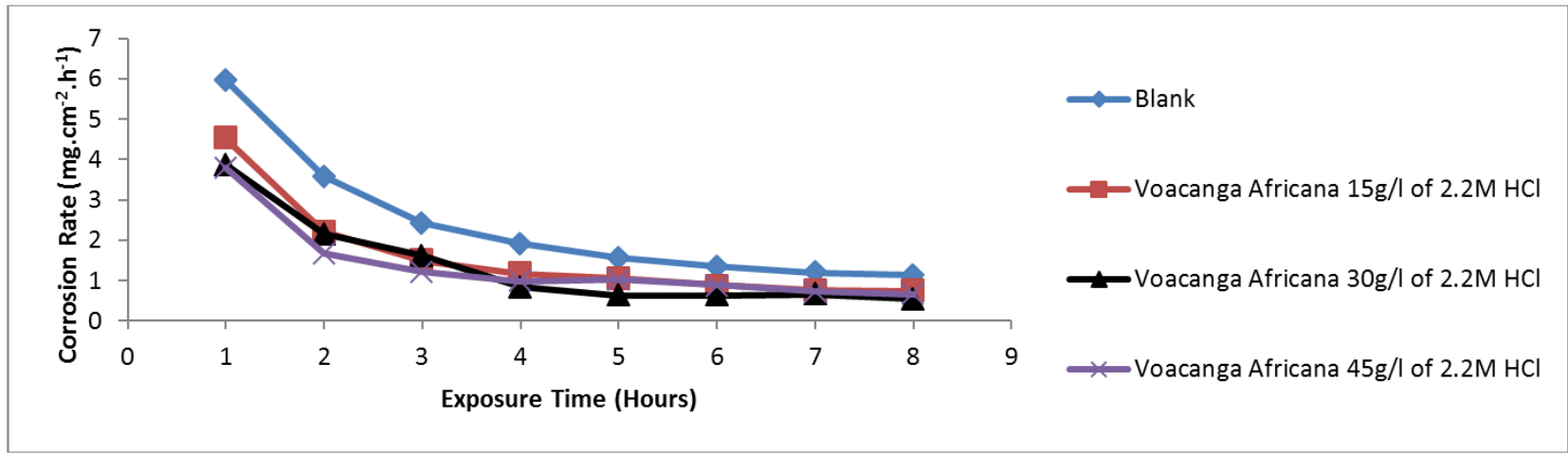

(c)

Figure 3. Effect of addition of thoroughly crushed leaves of Voacanga Africana on corrosion of mild steel coupons immersed at: (a) $15 \mathrm{~g} / \mathrm{l}, 30 \mathrm{~g} / \mathrm{l}$ and $45 \mathrm{~g} / \mathrm{l}$ of $0.7 \mathrm{M} \mathrm{HCl}$, (b) $15 \mathrm{~g} / \mathrm{l}, 30 \mathrm{~g} / \mathrm{l}$ and $45 \mathrm{~g} / \mathrm{l}$ of $1.2 \mathrm{M} \mathrm{HCl}$, (c) $15 \mathrm{~g} / \mathrm{l}, 30 \mathrm{~g} / \mathrm{l}$ and $45 \mathrm{~g} / \mathrm{l}$ of $2.2 \mathrm{M} \mathrm{HCl}$.

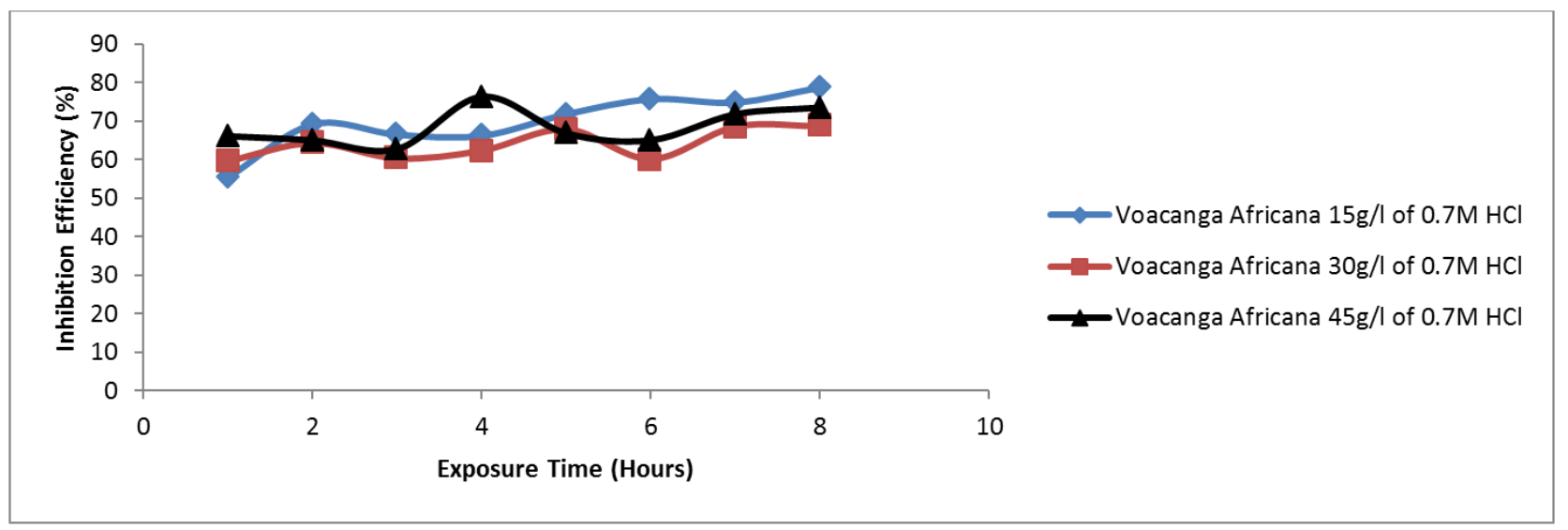

(a)

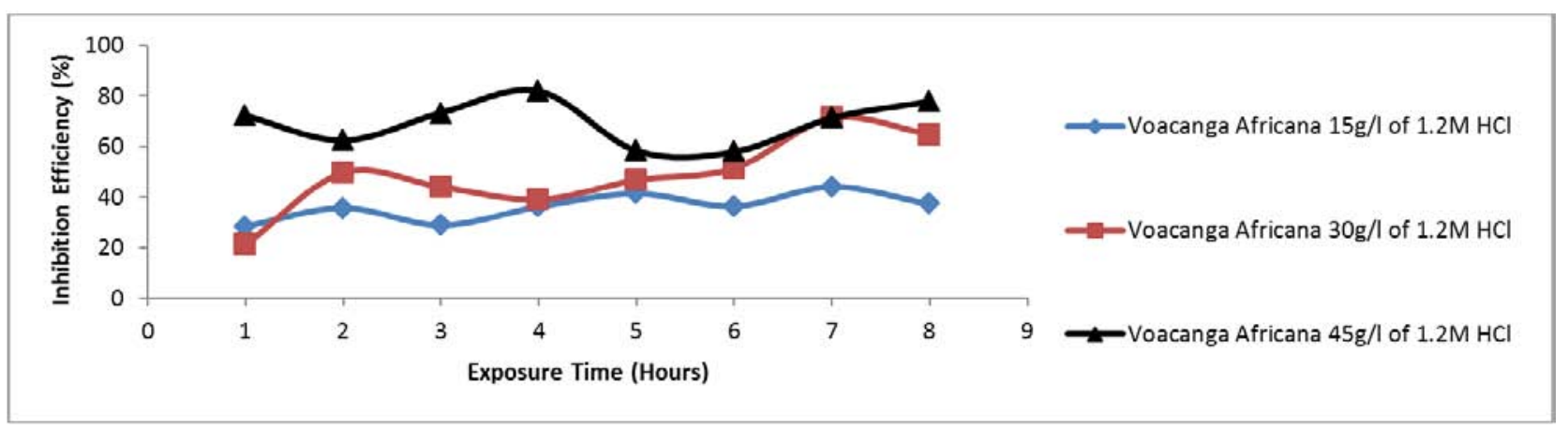

(b) 


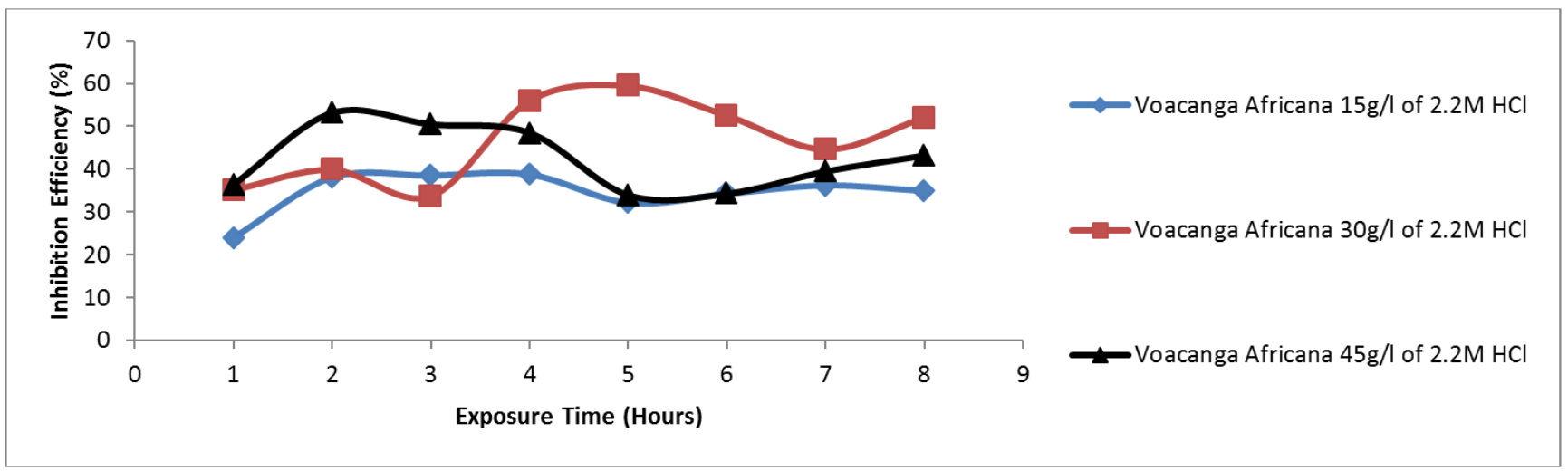

(c)

Figure 4. Voacanga Africana's corrosion inhibition efficiency for mild steel coupons immersed at: (a) $15 \mathrm{~g} / \mathrm{l}, 30 \mathrm{~g} / \mathrm{l}$ and $45 \mathrm{~g} / \mathrm{l}$ of $0.7 \mathrm{MHCl}$, (b) $15 \mathrm{~g} / \mathrm{l}$, $30 \mathrm{~g} / \mathrm{l}$ and $45 \mathrm{~g} / \mathrm{l}$ of $1.2 \mathrm{MHCl}$, (c) $15 \mathrm{~g} / \mathrm{l}, 30 \mathrm{~g} / \mathrm{l}$ and $45 \mathrm{~g} / \mathrm{l}$ of $2.2 \mathrm{MHCl}$.

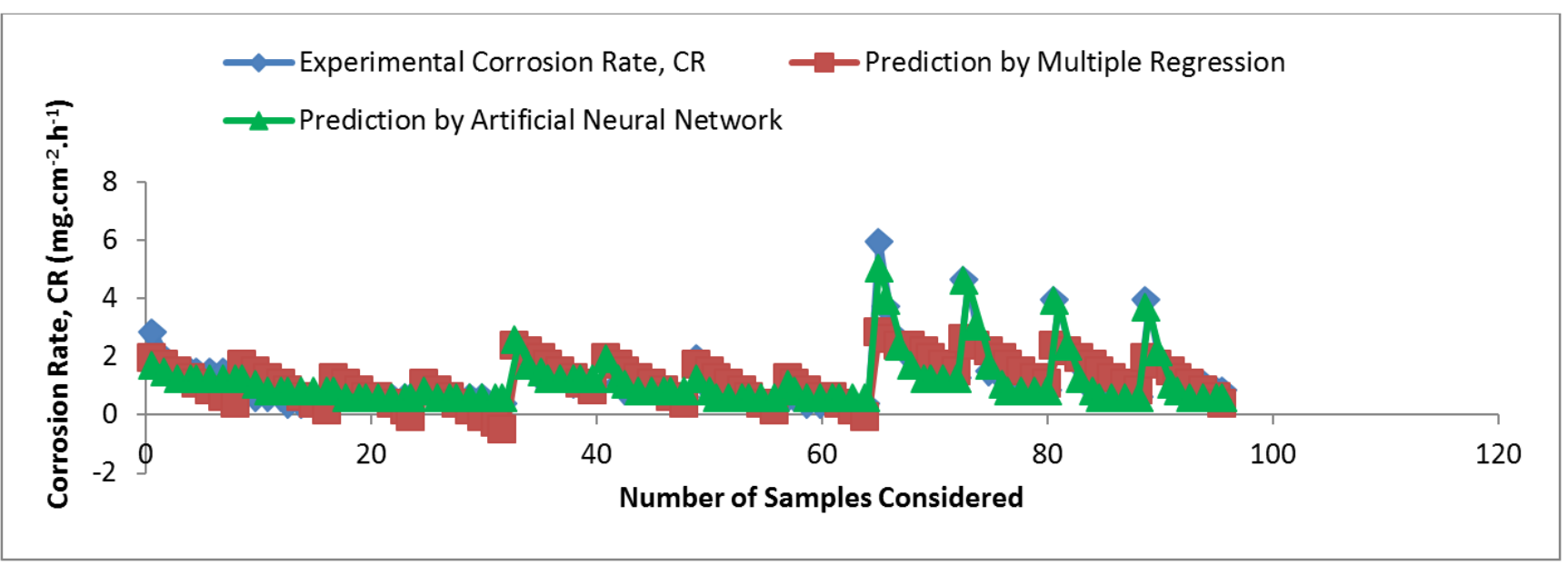

Figure 5. Comparison of error for the prediction of corrosion inhibition of mild steel in hydrochloric acid by thoroughly crushed leaves of Voacanga Africana using multiple regression, MR and artificial neural network, ANN.

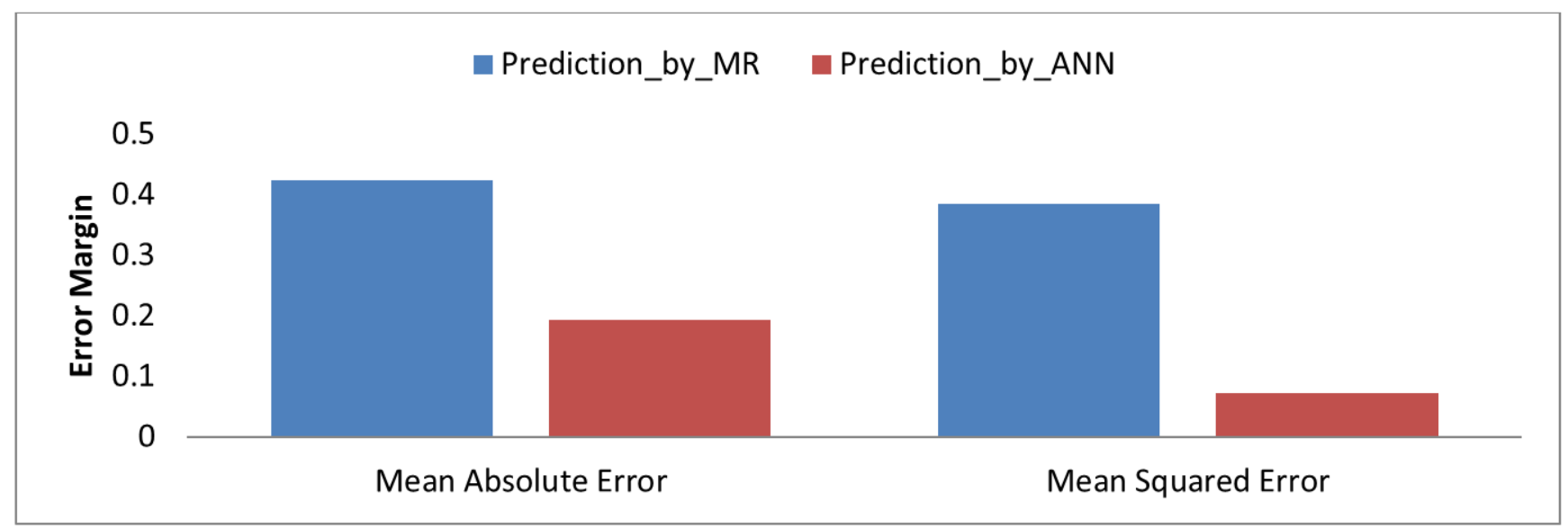

Figure 6. Error graph for the prediction of corrosion inhibition of mild steel in hydrochloric acid by thoroughly crushed leaves of Voacanga Africana using multiple regression, MR and artificial neural network, $A N N$.

Table 2. Analysis for prediction of corrosion inhibition of mild steel in hydrochloric acid by thoroughly crushed leaves of Voacanga Africana using multiple regression (MR).

\begin{tabular}{lllll}
\hline & Model Coefficients & & \\
\cline { 2 - 5 } & Constant & Time (h) & Conc. of Acid (M) & Quantity of Crushed Leaves (g) \\
\hline $\mathrm{HCl}$ & 1.670 & -0.213 & 0.628 & -0.021 \\
\hline
\end{tabular}


Table 3. Analysis for the prediction of corrosion inhibition of mild steel in hydrochloric acid by thoroughly crushed leaves of Voacanga Africana using artificial neural network $(A N N)$.

\begin{tabular}{lll}
\hline \multicolumn{2}{l}{ Independent variable importance for the addition of thoroughly crushed leaves of Voacanga Africana in hydrochloric acid } \\
\hline & Importance & Normalized Importance \\
\hline Time & 0.496 & $100.0 \%$ \\
Conc_of_HCl & 0.242 & $48.8 \%$ \\
Quantity_of_VA_Extract & 0.262 & $52.8 \%$ \\
\hline
\end{tabular}

Table 3. Continue.

\begin{tabular}{|c|c|c|c|c|}
\hline \multicolumn{5}{|c|}{ Parameter Estimates for the addition of thoroughly crushed leaves of Voacanga Africana in hydrochloric acid } \\
\hline \multirow{3}{*}{ Predictor } & & \multicolumn{3}{|c|}{ Predicted } \\
\hline & & \multicolumn{2}{|c|}{ Hidden Layer 1} & \multirow{2}{*}{$\begin{array}{l}\text { Output Layer } \\
\text { Exp_Corrosion_Rate }\end{array}$} \\
\hline & & $\mathrm{H}(1: 1)$ & H(1:2) & \\
\hline \multirow{4}{*}{ Input Layer } & (Bias) & 1.019 & 4.542 & \\
\hline & Time & 0.174 & 2.282 & \\
\hline & Conc_of_HCl & 0.056 & -1.268 & \\
\hline & Quantity_of_VA_Extract & 1.949 & -0.021 & \\
\hline \multirow{3}{*}{ Hidden Layer 1} & (Bias) & & & 3.235 \\
\hline & $\mathrm{H}(1: 1)$ & & & -1.638 \\
\hline & $\mathrm{H}(1: 2)$ & & & -4.541 \\
\hline
\end{tabular}

Table 4. Error analysis for the prediction of corrosion inhibition of mild steel in hydrochloric acid by thoroughly crushed leaves of Voacanga Africana using multiple regression, $M R$ and artificial neural network, $A N N$.

\begin{tabular}{lll}
\hline Error & Prediction of CR by Multiple Regression, MR & Prediction of CR by Artificial Neural Network, ANN \\
\hline Mean Absolute Error & 0.423305417 & 0.193705208 \\
Mean Squared Error & 0.384576304 & 0.071829608 \\
\hline
\end{tabular}

Table 5. Effect of variation in temperature on the corrosion of mild steel coupons immersed at $15 \mathrm{~g}$ of Voacanga Africana's crushed fresh leaves per litre of $0.7 \mathrm{M} \mathrm{HCl}$.

\begin{tabular}{llllll}
\hline Temperature (K) & $\mathbf{C R}_{\mathbf{V A} \text { addition }}\left(\mathbf{m g} . \mathbf{c m}^{-\mathbf{2}} \cdot \mathbf{h}^{\mathbf{- 1}}\right)$ & $\mathbf{C R}_{\text {Blank }}\left(\mathbf{m g} . \mathbf{c m}^{-\mathbf{2}} \cdot \mathbf{h}^{\mathbf{- 1}}\right)$ & $\mathbf{L o g} \mathbf{C} \mathbf{R}_{\mathbf{V A} \text { addition }}$ & $\mathbf{L o g} \mathbf{C R}$ Blank & $\mathbf{1 / T}\left(\mathbf{K}^{\mathbf{1}}\right)$ \\
\hline 298 & 0.5115 & 1.6127 & -0.2912 & 0.2076 & 0.003356 \\
318 & 1.7779 & 5.4985 & 0.2499 & 0.7402 & 0.003145 \\
338 & 2.6064 & 6.4186 & 0.4160 & 0.8074 & 0.002959 \\
358 & 7.0779 & 0.5222 & 0.8499 & 0.002793 \\
\hline
\end{tabular}

Slope $_{\text {Blank }}=-1092 \mathrm{~K}^{-1}$, Slope $_{\mathrm{VA} \text { addition }}=-1395 \mathrm{~K}^{-1}$

Activation Energy, $Q_{B l a n k}=20,908.68 \mathrm{~J}$, Activation Energy, $Q_{\mathrm{VA} \text { addition }}=26,710.26 \mathrm{~J}$

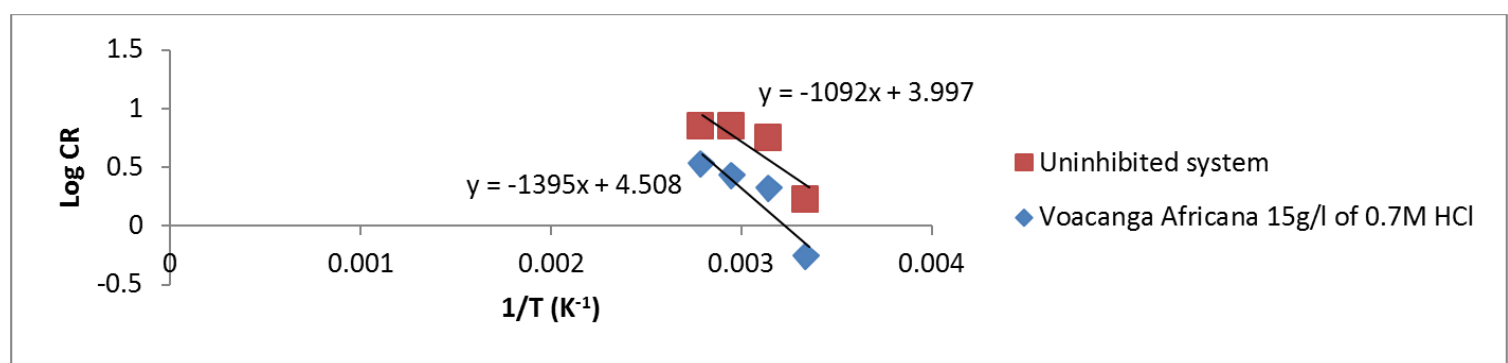

Figure 7. Arrhenius plot for the effect of addition of thoroughly crushed leaves of Voacanga Africana on corrosion of mild steel coupons immersed at $15 \mathrm{~g} / \mathrm{l}$ of $0.7 \mathrm{M} \mathrm{HCl}$.

Table 6. Calculated parameters of four adsorption isotherm models for adsorption of thoroughly crushed fresh leaves of Voacanga Africana onto the surface of mild steel coupons in hydrochloric acid medium.

\begin{tabular}{llllllll}
\hline \multicolumn{2}{l}{ Adsorption Isotherm } & \multicolumn{2}{l}{} \\
\hline \multicolumn{2}{l}{ Langmuir } & Freundlich & & Temkin & & El-Awady \\
\hline Slope & $\mathrm{R}^{2}$ & Slope & $\mathrm{R}^{2}$ & Slope & $\mathrm{R}^{2}$ & Slope & $\mathrm{R}^{2}$ \\
1.475 & 0.992 & -0.029 & 0.128 & -0.02 & 0.134 & -0.091 & 0.139 \\
Parameters & & & & & & \\
$\mathrm{C}(\mathrm{g})$ & Log C & In C & $\Theta$ & $\mathrm{C} / \Theta$ & Log $\Theta$ & $1-\Theta$ & Log $(\Theta / 1-\Theta)$ \\
15 & 1.1761 & 2.7081 & 0.6980 & 21.4900 & -0.1561 & 0.3020 & 0.3638 \\
30 & 1.4771 & 3.4012 & 0.6401 & 46.8677 & -0.1938 & 0.3599 & 0.2501 \\
45 & 1.6532 & 3.8067 & 0.6845 & 65.7414 & -0.1646 & 0.3155 & 0.3364 \\
\hline
\end{tabular}




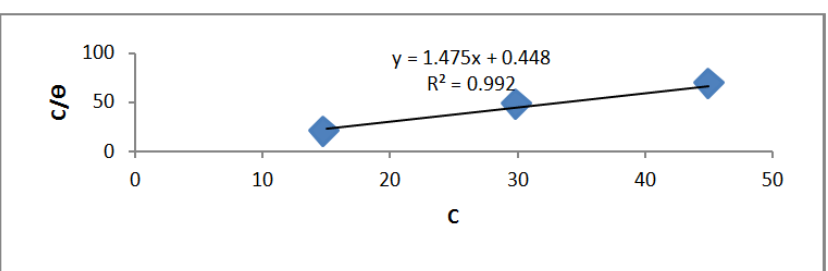

(a)

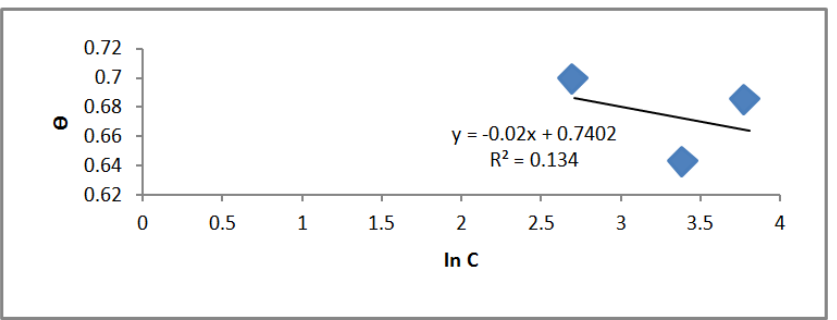

(c)

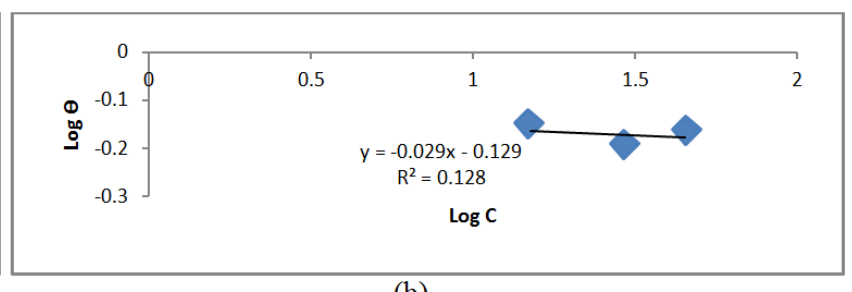

(b)

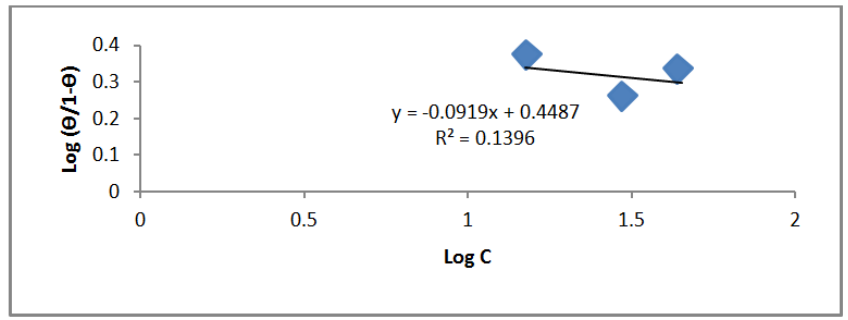

(d)

Figure 8. Adsorption Isotherm models for adsorption of the crushed leaves of Voacanga Africana on the mild steel surface in hydrochloric acid medium: (a) Langmuir adsorption isotherm (b) Freundlich adsorption isotherm (c) Temkin adsorption isotherm (d) El-Awady adsorption isotherm.

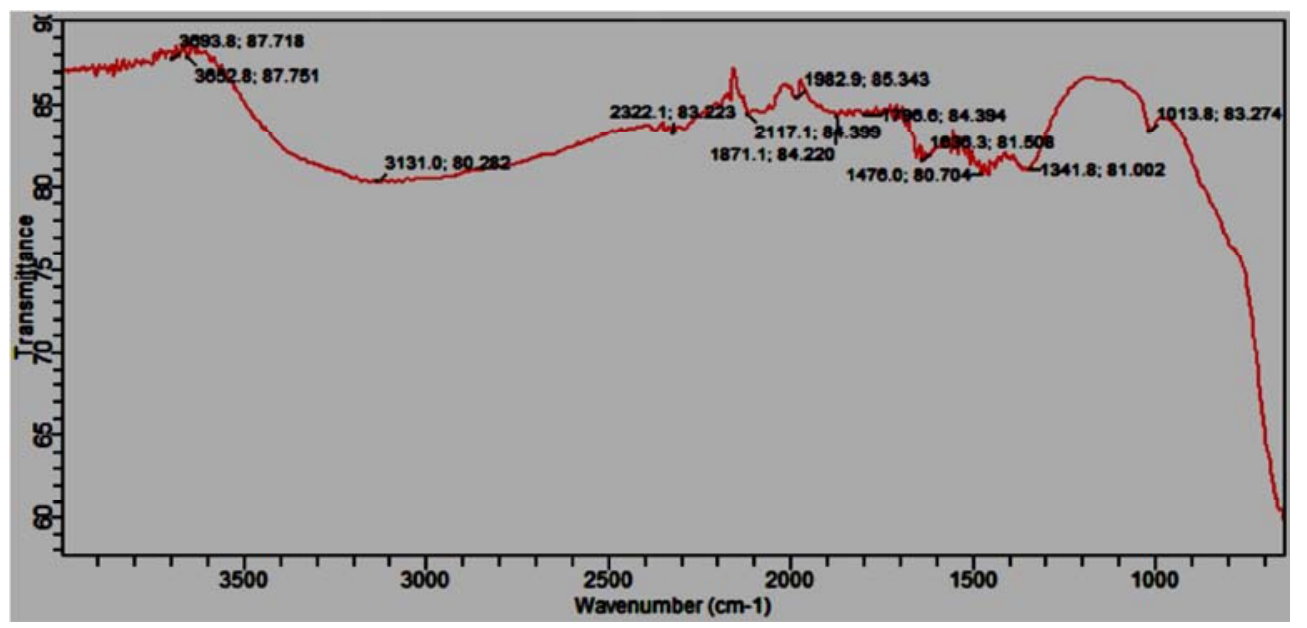

Figure 9. FTIR spectrum of film on mild steel surface after immersion in a medium containing thoroughly crushed leaves of Voacanga Africana at $30 \mathrm{~g}$ per litre of $0.7 \mathrm{M} \mathrm{HCl}$.

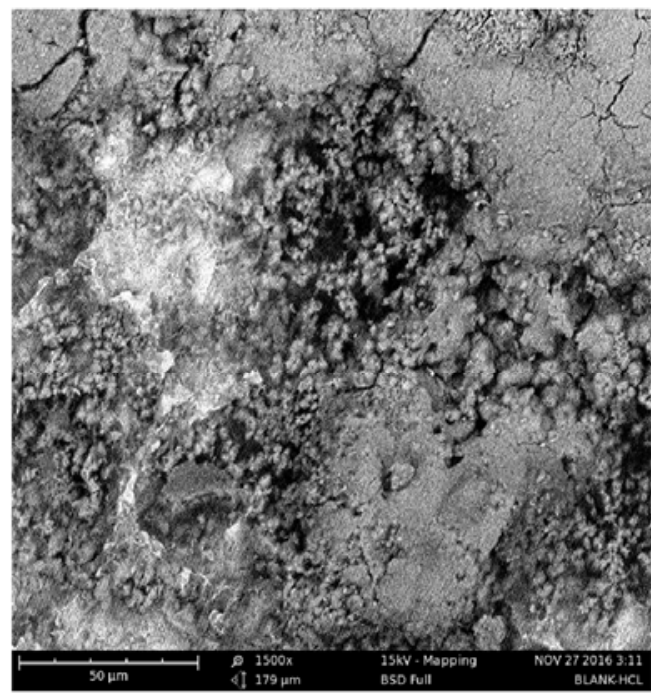

(a)

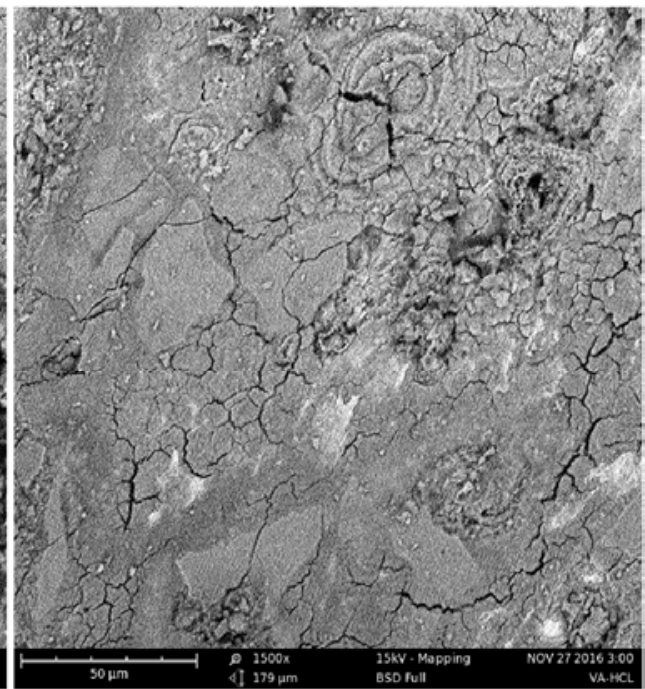

(b)

Figure 10. SEM features of the corroded mild steel in: (a) the blank solution of $0.7 \mathrm{M} \mathrm{HCl}$ (b) the presence of thoroughly crushed leaves of Voacanga Africana at $30 \mathrm{~g} / \mathrm{l}$ of $0.7 \mathrm{M} \mathrm{HCl}$. 


\section{Discussion of Results}

\subsection{Effect of Addition of Thoroughly Crushed Leaves of Voacanga Africana on the Corrosion of Mild Steel Coupons Immersed in Hydrochloric Acid Solution}

The average corrosion rate, $\mathrm{CR}$ and inhibition efficiency, I.E in the order CR (I.E) as presented in Table 1 for the addition of Voacanga Africana's crushed leaves at $15 \mathrm{~g}$ per litre of $0.7 \mathrm{M}, 1.2 \mathrm{M}$ and $2.2 \mathrm{M} \mathrm{HCl}$ gave the following: $0.5115 \mathrm{mg} \cdot \mathrm{cm}^{-2} \cdot \mathrm{h}^{-1}(69.80 \%)$ in $0.7 \mathrm{M} \mathrm{HCl} ; 0.8385 \mathrm{mg} \cdot \mathrm{cm}^{-2} \cdot \mathrm{h}^{-1}$ $(36.06 \%)$ in $1.2 \mathrm{M} \mathrm{HCl}$ and $1.6095 \mathrm{mg}^{-\mathrm{cm}^{-2}} \cdot \mathrm{h}^{-1}(34.60 \%)$ in 2.2M HCl. As the addition of the crushed leaves was increased to $30 \mathrm{~g}$ per litre of various acid concentrations, the corresponding average corrosion rate and inhibition efficiency were: $0.5869 \mathrm{mg} \cdot \mathrm{cm}^{-2} \cdot \mathrm{h}^{-1}(64.01 \%)$ in $0.7 \mathrm{M} \mathrm{HCl}$; $0.7118 \mathrm{mg} \cdot \mathrm{cm}^{-2} \cdot \mathrm{h}^{-1}(48.52 \%)$ in $1.2 \mathrm{M} \mathrm{HCl}$ and $0.5525 \mathrm{mg} . \mathrm{cm}^{-}$ ${ }^{2} \cdot \mathrm{h}^{-1}(46.63 \%)$ in $2.2 \mathrm{M} \mathrm{HCl}$. Further addition of the crushed leaves at $45 \mathrm{~g}$ per litre of different acid concentrations gave the following average corrosion rate and inhibition efficiency: $\quad 0.5145 \mathrm{mg} \cdot \mathrm{cm}^{-2} \cdot \mathrm{h}^{-1}(68.45 \%)$ in $0.7 \mathrm{M} \mathrm{HCl}$; $0.3967 \mathrm{mg} \cdot \mathrm{cm}^{-2} \cdot \mathrm{h}^{-1}(68.65 \%)$ in $1.2 \mathrm{M} \mathrm{HCl}$ and $1.3700 \mathrm{mg} . \mathrm{cm}^{-}$ ${ }^{2} \cdot \mathrm{h}^{-1}(42.40 \%)$ in $2.2 \mathrm{M} \mathrm{HCl}$. The addition of thoroughly crushed leaves of Voacanga Africana reduced the corrosion of mild steel coupons in hydrochloric acid medium. The corrosion rate was observed to increase with increase in the concentration of acid whilst the inhibition efficiency improved with time.

$$
\mathrm{CR}_{\mathrm{VA} \text { in } \mathrm{HCl} \text { by MR }}=1.670-0.213 \text { (time) }+0.628 \text { (conc. of acid) }-0.021 \text { (quantity of crushed leaves) }
$$

On the other hand, the prediction of the experimental corrosion rate of mild steel by artificial neural network revealed the importance of the following independent variables: (time of exposure $(\mathrm{h})$, concentration of acid $(\mathrm{M})$ and quantity of crushed leaves $(\mathrm{g}))$ in the prediction of the dependent variable (Corrosion rate, $\mathrm{CR}\left(\mathrm{mg} \cdot \mathrm{cm}^{-2} \cdot \mathrm{h}^{-1}\right)$ as illustrated in Table 3. The time of exposure was found to largely influence the prediction of the corrosion rate by $49.6 \%$, followed by the quantity of crushed leaves, $26.2 \%$ and finally the concentration of acid, $24.2 \%$.

The comparison of error results for the prediction of corrosion inhibition of mild steel by Voacanga Africana's crushed leaves in hydrochloric acid using multiple regression and artificial neural network are presented in Table 4 and displayed in Figures 5 and 6 . The results show that predictions by the artificial neural network gave a minimal error and were closer to the experimental corrosion rate values in comparison with predictions by multiple regression.

\subsection{Effect of Variation in Temperature on the Corrosion of Mild Steel Coupons Immersed at $15 \mathrm{~g}$ of Voacanga Africana's Thoroughly Crushed Leaves Per Litre of $0.7 \mathrm{M} \mathrm{HCl}$}

The result of the variation in temperature between $298 \mathrm{~K}$ and $358 \mathrm{~K}$ on the corrosion of mild steel without and with the addition of thoroughly crushed leaves of Voacanga Africana
The corrosion rate-time curves for the mild steel coupons dipped in $0.7 \mathrm{M}, 1.2 \mathrm{M}$ and $2.2 \mathrm{M} \mathrm{HCl}$ in the presence and absence of Voacanga Africana's crushed leaves are displayed in Figure 3. The corrosion-rate curves were observed to decrease progressively as the exposure time increased. On the other hand, the inhibition efficiency-time curves for the corrosion inhibition of mild steel coupons occasioned by the addition of Voacanga Africana's crushed leaves at $15 \mathrm{~g}$ per litre, $30 \mathrm{~g}$ per litre and $45 \mathrm{~g}$ per litre of $0.7 \mathrm{M}, 1.2 \mathrm{M}$ and $2.2 \mathrm{M}$ $\mathrm{HCl}$ are shown in Figure 4. The inhibition efficiency curves increased as the experimentation progressed. The maximum inhibition efficiency of $69.80 \%$ was obtained when thoroughly crushed leaves of Voacanga Africana was added at $15 \mathrm{~g}$ per litre of $0.7 \mathrm{M} \mathrm{HCl}$ with a corresponding decrease in corrosion rate from $2.6487 \mathrm{mg} \cdot \mathrm{cm}^{-2} \cdot \mathrm{h}^{-1}$ to $1.3684 \mathrm{mg} \cdot \mathrm{cm}^{-2} \cdot \mathrm{h}^{-1}$.

\subsection{Prediction of Corrosion Inhibition of Mild Steel in Hydrochloric Acid by Thoroughly Crushed Leaves of Voacanga Africana}

Multiple regression and artificial neural network were used to predict the corrosion inhibition of mild steel in hydrochloric acid by Voacanga Africana's crushed leaves. The predicted values are illustrated in Appendix 1. Using multiple regression as presented in Table 2, the predictive equation for the corrosion inhibition of mild steel by thoroughly crushed leaves of Voacanga Africana in hydrochloric acid medium is stated below:

at $15 \mathrm{~g}$ per litre of $0.7 \mathrm{M} \mathrm{HCl}$ is presented in Table 5 and displayed in Figure 7. The activation energy obtained for the corrosion of mild steel in the blank solution of $0.7 \mathrm{M} \mathrm{HCl}$ was 20,908.68J while the addition of Voacanga Africana's crushed leaves at $15 \mathrm{~g}$ per litre of $0.7 \mathrm{M} \mathrm{HCl}$ increased the activation energy to $26,710.26 \mathrm{~J}$. The higher value of activation energy obtained by the introduction of the crushed leaves of Voacanga Africana to the corrodent suggests that more energy needs to be attained before further corrosion can take place.

\subsection{Adsorption Isotherm for the Corrosion Inhibition of Mild Steel in Hydrochloric Acid by Thoroughly Crushed Leaves of Voacanga Africana}

Langmuir, Freundlich, Temkin and El-Awady adsorption isotherm models were tested and presented in Table 6 and Figure 8 for the corrosion inhibition of mild steel in hydrochloric acid by thoroughly crushed leaves of Voacanga Africana. Of all the tested models, only the Langmuir adsorption isotherm $\left(\mathrm{R}^{2}=0.992\right)$ was obeyed. This development reveals that corrosion inhibition was achieved by the adsorption of a monolayer of the inhibitive constituents of Voacanga Africana's crushed leaves on the surface of mild steel. The Langmuir adsorption isotherm model is expressed by the relationship:

$$
\mathrm{C}_{\text {inhibitor }} / \Theta=\mathrm{C}_{\text {inhibitor }}+1 / \mathrm{K}
$$


Where,

$C_{\text {inhibitor }}=$ Concentration of the inhibitor.

$\theta=$ Fraction of surface coverage.

$k=$ Equilibrium constant for the adsorption process.

\subsection{FTIR Analysis of the Corrosion Inhibition of Mild Steel in Hydrochloric Acid by Thoroughly Crushed Leaves of Voacanga Africana}

The FTIR spectrum of the adhered constituents of Voacanga Africana's crushed leaves on the surface of mild steel coupon immersed at $30 \mathrm{~g}$ per litre of $0.7 \mathrm{M} \mathrm{HCl}$ for eight hours is shown in Figure 9. The $\mathrm{O}-\mathrm{H}$ functional group is spotted around $3652.8 \mathrm{~cm}^{-1}$. The presence of carbon-carbon triple bond of alkynes is indicated at $2117.8 \mathrm{~cm}^{-1}$. The display of a sharp band around the frequency, $2117.8 \mathrm{~cm}^{-1}$ reveals a very polar functional group. The amide functional group of $\mathrm{C}=\mathrm{O}$ bond is found at $1676 \mathrm{~cm}^{-1}$ whilst the two spikes around $1676 \mathrm{~cm}^{-1}$ depicts the existence of primary amides.

\subsection{SEM Micrograph for the Corrosion Inhibition of Mild Steel in Hydrochloric Acid by Thoroughly Crushed Leaves of Voacanga Africana}

The SEM image shows that the deterioration of the surface of mild steel in an uninhibited solution of $0.7 \mathrm{M} \mathrm{HCl}$ is not uniform (Figure 10(a)) but, is somewhat protected by the addition of thoroughly crushed leaves of Voacanga Africana at $30 \mathrm{~g}$ per litre of $0.7 \mathrm{M} \mathrm{HCl}$ as shown in Figure 10(b).

\section{Conclusion}

The maximum inhibition efficiency of $69.80 \%$ was obtained when thoroughly crushed leaves of Voacanga Africana was added at $15 \mathrm{~g}$ per litre of $0.7 \mathrm{M} \mathrm{HCl}$ with a corresponding decrease in corrosion rate from $2.6487 \mathrm{mg} . \mathrm{cm}^{-}$ ${ }^{2} \cdot \mathrm{h}^{-1}$ to $1.3684 \mathrm{mg} \cdot \mathrm{cm}^{-2} \cdot \mathrm{h}^{-1}$. Predictions by the artificial neural network gave a minimal error and were closer to the experimental corrosion-rate values in comparison with predictions by multiple regression. The activation energy obtained for the corrosion of mild steel in the blank solution of $0.7 \mathrm{M} \mathrm{HCl}$ was $20,908.68 \mathrm{~J}$ while the addition of Voacanga Africana's crushed leaves at $15 \mathrm{~g}$ per litre of $0.7 \mathrm{M} \mathrm{HCl}$ increased the activation energy to $26,710.26 \mathrm{~J}$. The corrosion inhibition of mild steel in hydrochloric acid by thoroughly crushed leaves of Voacanga Africana obeyed the Langmuir adsorption isotherm with $\mathrm{R}^{2}=0.992$. The FTIR spectrum of the adhered constituents of Voacanga Africana's crushed leaves on the surface of mild steel coupon immersed at $30 \mathrm{~g}$ per litre of $0.7 \mathrm{M} \mathrm{HCl}$ for eight hours revealed the presence of $\mathrm{O}-\mathrm{H}$ functional group, carbon-carbon triple bond of alkynes and the amide functional group of $\mathrm{C}=\mathrm{O}$ bond.

\section{Appendix}

Table A1. Prediction of Corrosion Inhibition of Mild Steel in Hydrochloric Acid Medium by thoroughly Crushed Leaves of Voacanga Africana.

\begin{tabular}{|c|c|c|c|c|c|c|c|c|}
\hline \multirow{2}{*}{ Case } & \multirow{2}{*}{ Time (h) } & \multirow{2}{*}{$\begin{array}{l}\text { Conc_of_H } \\
\mathrm{Cl}(\mathrm{M})\end{array}$} & \multirow{2}{*}{$\begin{array}{l}\text { Quantity_of_VA_ } \\
\text { Crushed_Leaves(g) }\end{array}$} & \multirow{2}{*}{$\begin{array}{l}\text { Exp. Corrosion Rate } \\
\left(\mathrm{mg} \cdot \mathrm{cm}^{-2} \cdot \mathrm{h}^{-1}\right)\end{array}$} & \multicolumn{2}{|c|}{ Prediction_by_MR } & \multicolumn{2}{|c|}{ Prediction_by_ANN } \\
\hline & & & & & CR & Error & CR & Error \\
\hline 1 & 1 & 0.7 & 0 & 2.6487 & 1.89618 & 0.75252 & 1.6837 & 0.965 \\
\hline 2 & 2 & 0.7 & 0 & 1.8646 & 1.68281 & 0.18179 & 1.3689 & 0.4957 \\
\hline 3 & 3 & 0.7 & 0 & 1.3989 & 1.46944 & -0.07054 & 1.2470 & 0.1519 \\
\hline 4 & 4 & 0.7 & 0 & 1.4137 & 1.25606 & 0.15764 & 1.1939 & 0.2198 \\
\hline 5 & 5 & 0.7 & 0 & 1.4214 & 1.04269 & 0.37871 & 1.165 & 0.2564 \\
\hline 6 & 6 & 0.7 & 0 & 1.3684 & 0.82931 & 0.53909 & 1.1446 & 0.2238 \\
\hline 7 & 7 & 0.7 & 0 & 1.3924 & 0.61594 & 0.77646 & 1.1270 & 0.2654 \\
\hline 8 & 8 & 0.7 & 0 & 1.3934 & 0.40257 & 0.99083 & 1.1101 & 0.2833 \\
\hline 9 & 1 & 0.7 & 15 & 1.1908 & 1.58476 & -0.39396 & 1.1635 & 0.0273 \\
\hline 10 & 2 & 0.7 & 15 & 0.5751 & 1.37139 & -0.79629 & 0.9258 & -0.3507 \\
\hline 11 & 3 & 0.7 & 15 & 0.4686 & 1.15801 & -0.68941 & 0.8334 & -0.3648 \\
\hline 12 & 4 & 0.7 & 15 & 0.4778 & 0.94464 & -0.46684 & 0.7903 & -0.3125 \\
\hline 13 & 5 & 0.7 & 15 & 0.4008 & 0.73127 & -0.33047 & 0.7647 & -0.3639 \\
\hline 14 & 6 & 0.7 & 15 & 0.3325 & 0.51789 & -0.18539 & 0.7457 & -0.4132 \\
\hline 15 & 7 & 0.7 & 15 & 0.3502 & 0.30452 & 0.04568 & 0.7294 & -0.3792 \\
\hline 16 & 8 & 0.7 & 15 & 0.2962 & 0.09114 & 0.20506 & 0.7145 & -0.4183 \\
\hline 17 & 1 & 0.7 & 30 & 1.0688 & 1.27334 & -0.20454 & 0.7781 & 0.2907 \\
\hline 18 & 2 & 0.7 & 30 & 0.6651 & 1.05997 & -0.39487 & 0.6295 & 0.0356 \\
\hline 19 & 3 & 0.7 & 30 & 0.5547 & 0.84659 & -0.29189 & 0.5760 & -0.0213 \\
\hline 20 & 4 & 0.7 & 30 & 0.5322 & 0.63322 & -0.10102 & 0.5540 & -0.0218 \\
\hline 21 & 5 & 0.7 & 30 & 0.4560 & 0.41985 & 0.03615 & 0.5432 & -0.0872 \\
\hline 22 & 6 & 0.7 & 30 & 0.5450 & 0.20647 & 0.33853 & 0.5365 & 0.0085 \\
\hline 23 & 7 & 0.7 & 30 & 0.4373 & -0.0069 & 0.4442 & 0.5316 & -0.0943 \\
\hline 24 & 8 & 0.7 & 30 & 0.4358 & -0.22028 & 0.65608 & 0.5274 & -0.0916 \\
\hline 25 & 1 & 0.7 & 45 & 0.8974 & 0.96192 & -0.06452 & 0.6769 & 0.2205 \\
\hline 26 & 2 & 0.7 & 45 & 0.6520 & 0.74855 & -0.09655 & 0.5547 & 0.0973 \\
\hline
\end{tabular}




\begin{tabular}{|c|c|c|c|c|c|c|c|c|}
\hline \multirow{2}{*}{ Case } & \multirow{2}{*}{ Time (h) } & \multirow{2}{*}{$\begin{array}{l}\text { Conc_of_H } \\
\mathrm{Cl}(\mathrm{M})\end{array}$} & \multirow{2}{*}{$\begin{array}{l}\text { Quantity_of_VA_- } \\
\text { Crushed_Leaves(g) }\end{array}$} & \multirow{2}{*}{$\begin{array}{l}\text { Exp. Corrosion Rate } \\
\left(\mathbf{m g} \cdot \mathrm{cm}^{-2} \cdot \mathrm{h}^{-1}\right)\end{array}$} & \multicolumn{2}{|c|}{ Prediction_by_MR } & \multicolumn{2}{|c|}{ Prediction_by_ANN } \\
\hline & & & & & CR & Error & CR & Error \\
\hline 27 & 3 & 0.7 & 45 & 0.5207 & 0.53517 & -0.01447 & 0.5128 & 0.0079 \\
\hline 28 & 4 & 0.7 & 45 & 0.3340 & 0.3218 & 0.0122 & 0.4973 & -0.1633 \\
\hline 29 & 5 & 0.7 & 45 & 0.4711 & 0.10842 & 0.36268 & 0.4911 & -0.0200 \\
\hline 30 & 6 & 0.7 & 45 & 0.4778 & -0.10495 & 0.58275 & 0.4883 & -0.0105 \\
\hline 31 & 7 & 0.7 & 45 & 0.3925 & -0.31832 & 0.71082 & 0.4868 & -0.0943 \\
\hline 32 & 8 & 0.7 & 45 & 0.3688 & -0.5317 & 0.9005 & 0.4858 & -0.1170 \\
\hline 33 & 1 & 1.2 & 0 & 2.2857 & 2.21006 & 0.07564 & 2.4601 & -0.1744 \\
\hline 34 & 2 & 1.2 & 0 & 1.5683 & 1.99668 & -0.42838 & 1.6580 & -0.0897 \\
\hline 35 & 3 & 1.2 & 0 & 1.1109 & 1.78331 & -0.67241 & 1.3450 & -0.2341 \\
\hline 36 & 4 & 1.2 & 0 & 1.1753 & 1.56994 & -0.39464 & 1.2235 & -0.0482 \\
\hline 37 & 5 & 1.2 & 0 & 1.1838 & 1.35656 & -0.17276 & 1.1700 & 0.0138 \\
\hline 38 & 6 & 1.2 & 0 & 1.0470 & 1.14319 & -0.09619 & 1.1405 & -0.0935 \\
\hline 39 & 7 & 1.2 & 0 & 1.0447 & 0.92981 & 0.11489 & 1.1194 & -0.0747 \\
\hline 40 & 8 & 1.2 & 0 & 0.9276 & 0.71644 & 0.21116 & 1.1010 & -0.1734 \\
\hline 41 & 1 & 1.2 & 15 & 1.6351 & 1.89864 & -0.26354 & 1.7676 & -0.1325 \\
\hline 42 & 2 & 1.2 & 15 & 1.0078 & 1.68526 & -0.67746 & 1.1255 & -0.1177 \\
\hline 43 & 3 & 1.2 & 15 & 0.7900 & 1.47189 & -0.68189 & 0.8951 & -0.1051 \\
\hline 44 & 4 & 1.2 & 15 & 0.7493 & 1.25852 & -0.50922 & 0.8059 & -0.0566 \\
\hline 45 & 5 & 1.2 & 15 & 0.6936 & 1.04514 & -0.35154 & 0.7645 & -0.0709 \\
\hline 46 & 6 & 1.2 & 15 & 0.6661 & 0.83177 & -0.16567 & 0.7401 & -0.0740 \\
\hline 47 & 7 & 1.2 & 15 & 0.5838 & 0.61839 & -0.03459 & 0.7220 & -0.1382 \\
\hline 48 & 8 & 1.2 & 15 & 0.582 & 0.40502 & 0.17698 & 0.7067 & -0.1247 \\
\hline 49 & 1 & 1.2 & 30 & 1.8007 & 1.58722 & 0.21348 & 1.2070 & 0.5937 \\
\hline 50 & 2 & 1.2 & 30 & 0.7900 & 1.37384 & -0.58384 & 0.7653 & 0.0247 \\
\hline 51 & 3 & 1.2 & 30 & 0.6215 & 1.16047 & -0.53897 & 0.6198 & 0.0017 \\
\hline 52 & 4 & 1.2 & 30 & 0.7166 & 0.9471 & -0.23050 & 0.5677 & 0.1489 \\
\hline 53 & 5 & 1.2 & 30 & 0.6302 & 0.73372 & -0.10352 & 0.5465 & 0.0837 \\
\hline 54 & 6 & 1.2 & 30 & 0.5087 & 0.52035 & -0.01165 & 0.5362 & -0.0275 \\
\hline 55 & 7 & 1.2 & 30 & 0.3004 & 0.30697 & -0.00657 & 0.5301 & -0.2297 \\
\hline 56 & 8 & 1.2 & 30 & 0.3264 & 0.0936 & 0.23280 & 0.5256 & -0.1992 \\
\hline 57 & 1 & 1.2 & 45 & 0.6354 & 1.2758 & -0.6404 & 1.0557 & -0.4203 \\
\hline 58 & 2 & 1.2 & 45 & 0.5896 & 1.06242 & -0.47282 & 0.6749 & -0.0853 \\
\hline 59 & 3 & 1.2 & 45 & 0.2962 & 0.84905 & -0.55285 & 0.553 & -0.2568 \\
\hline 60 & 4 & 1.2 & 45 & 0.2127 & 0.63567 & -0.42297 & 0.5112 & -0.2985 \\
\hline 61 & 5 & 1.2 & 45 & 0.4932 & 0.4223 & 0.07090 & 0.4959 & -0.0027 \\
\hline 62 & 6 & 1.2 & 45 & 0.4410 & 0.20893 & 0.23207 & 0.4898 & -0.0488 \\
\hline 63 & 7 & 1.2 & 45 & 0.2996 & -0.00445 & 0.30405 & 0.4871 & -0.1875 \\
\hline 64 & 8 & 1.2 & 45 & 0.2062 & -0.21782 & 0.42402 & 0.4857 & -0.2795 \\
\hline 65 & 1 & 2.2 & 0 & 5.9626 & 2.83781 & 3.12479 & 5.0362 & 0.9264 \\
\hline 66 & 2 & 2.2 & 0 & 3.5723 & 2.62444 & 0.94786 & 3.8548 & -0.2825 \\
\hline 67 & 3 & 2.2 & 0 & 2.4367 & 2.41106 & 0.02564 & 2.3956 & 0.0411 \\
\hline 68 & 4 & 2.2 & 0 & 1.9052 & 2.19769 & -0.29249 & 1.6007 & 0.3045 \\
\hline 69 & 5 & 2.2 & 0 & 1.5683 & 1.98431 & -0.41601 & 1.2925 & 0.2758 \\
\hline 70 & 6 & 2.2 & 0 & 1.3462 & 1.77094 & -0.42474 & 1.1723 & 0.1739 \\
\hline 71 & 7 & 2.2 & 0 & 1.2016 & 1.55757 & -0.35597 & 1.1184 & 0.0832 \\
\hline 72 & 8 & 2.2 & 0 & 1.1519 & 1.34419 & -0.19229 & 1.0878 & 0.0641 \\
\hline 73 & 1 & 2.2 & 15 & 4.5307 & 2.52639 & 2.00431 & 4.5084 & 0.0223 \\
\hline 74 & 2 & 2.2 & 15 & 2.2131 & 2.31302 & -0.09992 & 3.0493 & -0.8362 \\
\hline 75 & 3 & 2.2 & 15 & 1.4986 & 2.09964 & -0.60104 & 1.6646 & -0.1660 \\
\hline 76 & 4 & 2.2 & 15 & 1.1668 & 1.88627 & -0.71947 & 1.0536 & 0.1132 \\
\hline 77 & 5 & 2.2 & 15 & 1.0647 & 1.67289 & -0.60819 & 0.8377 & 0.2270 \\
\hline 78 & 6 & 2.2 & 15 & 0.8853 & 1.45952 & -0.57422 & 0.7549 & 0.1304 \\
\hline 79 & 7 & 2.2 & 15 & 0.7667 & 1.24615 & -0.47945 & 0.7170 & 0.0497 \\
\hline 80 & 8 & 2.2 & 15 & 0.7497 & 1.03277 & -0.28307 & 0.6950 & 0.0547 \\
\hline 81 & 1 & 2.2 & 30 & 3.8686 & 2.21497 & 1.65363 & 3.8377 & 0.0309 \\
\hline 82 & 2 & 2.2 & 30 & 2.1492 & 2.00159 & 0.14761 & 2.3089 & -0.1597 \\
\hline 83 & 3 & 2.2 & 30 & 1.6167 & 1.78822 & -0.17152 & 1.1722 & 0.4445 \\
\hline 84 & 4 & 2.2 & 30 & 0.8394 & 1.57485 & -0.73545 & 0.7435 & 0.0959 \\
\hline
\end{tabular}




\begin{tabular}{|c|c|c|c|c|c|c|c|c|}
\hline \multirow{2}{*}{ Case } & \multirow{2}{*}{ Time (h) } & \multirow{2}{*}{$\begin{array}{l}\text { Conc_of_H } \\
\mathrm{Cl}(\mathrm{M})\end{array}$} & \multirow{2}{*}{$\begin{array}{l}\text { Quantity_of_VA_- } \\
\text { Crushed_Leaves(g) }\end{array}$} & \multirow{2}{*}{$\begin{array}{l}\text { Exp. Corrosion Rate } \\
\left(\mathbf{m g} \cdot \mathbf{c m}^{-2} \cdot \mathbf{h}^{-1}\right)\end{array}$} & \multicolumn{2}{|c|}{ Prediction_by_MR } & \multicolumn{2}{|c|}{ Prediction_by_ANN } \\
\hline & & & & & $\mathbf{C R}$ & Error & CR & Error \\
\hline 85 & 5 & 2.2 & 30 & 0.6366 & 1.36147 & -0.72487 & 0.6032 & 0.0334 \\
\hline 86 & 6 & 2.2 & 30 & 0.6399 & 1.14810 & -0.5082 & 0.5535 & 0.0864 \\
\hline 87 & 7 & 2.2 & 30 & 0.6659 & 0.93472 & -0.26882 & 0.5337 & 0.1322 \\
\hline 88 & 8 & 2.2 & 30 & 0.5525 & 0.72135 & -0.16885 & 0.5244 & 0.0281 \\
\hline 89 & 1 & 2.2 & 45 & 3.793 & 1.90355 & 1.88945 & 3.5951 & 0.1979 \\
\hline 90 & 2 & 2.2 & 45 & 1.6743 & 1.69017 & -0.01587 & 2.0981 & -0.4238 \\
\hline 91 & 3 & 2.2 & 45 & 1.2072 & 1.4768 & -0.2696 & 1.0524 & 0.1548 \\
\hline 92 & 4 & 2.2 & 45 & 0.9817 & 1.26343 & -0.28173 & 0.6718 & 0.3099 \\
\hline 93 & 5 & 2.2 & 45 & 1.0363 & 1.05005 & -0.01375 & 0.5502 & 0.4861 \\
\hline 94 & 6 & 2.2 & 45 & 0.8853 & 0.83668 & 0.04862 & 0.5086 & 0.3767 \\
\hline 95 & 7 & 2.2 & 45 & 0.7277 & 0.6233 & 0.10440 & 0.4934 & 0.2343 \\
\hline 96 & 8 & 2.2 & 45 & 0.6546 & 0.40993 & 0.24467 & 0.4875 & 0.1671 \\
\hline
\end{tabular}

\section{References}

[1] Bartholomew, R. D., \& Shelfler, D. A. (1996). Corrosion. Avallone, E. A., Baumeister III, T., (Eds), Marks' standard handbook for Mechanical Engineering, (10 ${ }^{\text {th }}$ Ed., pp. 6-(95107). New York: Mc-Graw Hill.

[2] Sharma, B. K. (2011). Industrial Chemistry [Including Chemical Engineering]. India: Krishna Press, p. 1698-1708.

[3] Chong, C. V. Y. (1981). Properties of Materials (p. 224-230). Britain: Chaucer Press.

[4] Lagrenée M., Mernari, B., Bouanis M., Traisnel M., \& Bentiss F. (2002). Study of the mechanism and inhibiting efficiency of 3, 5-bis (4-methylthiophenyl)-4H-1, 2, 4-triazole on mild steel corrosion in acidic media. Corros Sci. 44, 573-588.

[5] Su, J. O, Jeongim, P., Min, J. L., So, Y. P., \&Kyungho, C. (2006). Ecological hazard assessment of major veterinary benzimidazoles: Acute and chronic toxicities to aquatic microbes and invertebrates. EnvTox Chem. 25, 2221-2226.

[6] Minling, G., Wenhua, S., \& Xiaoying, C. (2010). The acute toxicity of triazoles to earthworms using a simple paper contact method. 4th Intl. Conf. Bioinform. Biomed. Engg DOI 10.1109/ICBBE. 2010.5515198.

[7] Martin, M. T., Brennan, R. J., Hu, W., Ayanoglu, E., Lau, C., Ren, H., Wood, C. R., Corton, J. C., Kavlock, R. J., \& Dix, D. J. (2007). Toxicogenomic study of triazole fungicides and perfluoroalkyl acids in rat livers predicts toxicity and categorizes chemicals based zon mechanism of toxicity. Toxicol Sci. 97, 595- 613.
[8] Hofmann, A., Ratsch, C., \& Shultes, R. (1992). Plants of Gods: Their Sacred, Healing, and Hallucination Powers. USA: Healing Arts press.

[9] Ndukwe, A. I. and Anyakwo, C. N. (2017). Modelling of Corrosion Inhibition of Mild Steel in Sulphuric Acid by thoroughly Crushed Leaves of Voacanga Africana (Apocynaceae). AJER, 6 (1), 344-356. http://www.ajer.org/papers/v6(01)/ZX060344356.pdf

[10] Cleversley, K., (n.d.). Retrieved May 3, 2015, from http://www.entheology.com/plants/vocanga-vocanga

[11] Neural Networks (2012). ANN - Artificial Neural Networks. Engineering Garage. Retrieved May 27, 2017 from https://www.engineersgarage.com/articles/artificial-neuralnetworks

[12] Khadom, A. A. (2014). Effect of Temperature on Corrosion Inhibition of Copper - Nickel Alloy by Tetraethylenepentamine underflow Conditions. Journal of the Chilean Chemical Society, 59 (3), 2545-2549.

[13] Negnevitsky, M. (2005) Artificial Intelligence, A guide to Intelligence Systems. Retrieved January 3, 2016 from http://www.academia.dk/BiologiskAntropologi/Epidemiologi/ DataMining/Artificial_IntelligenceA_Guide_to_Intelligent_Systems.pdf

[14] Nasr, M. S., Moustafa, M. A. E., Seif, H. A. E., \& El Kobrosy, G. (2012). Application of Artificial Neural Network (ANN) for the prediction of EL-AGAMY waste water treatment plant performance- EGYPT. Alexandria Engineering Journal 51, 3743. 